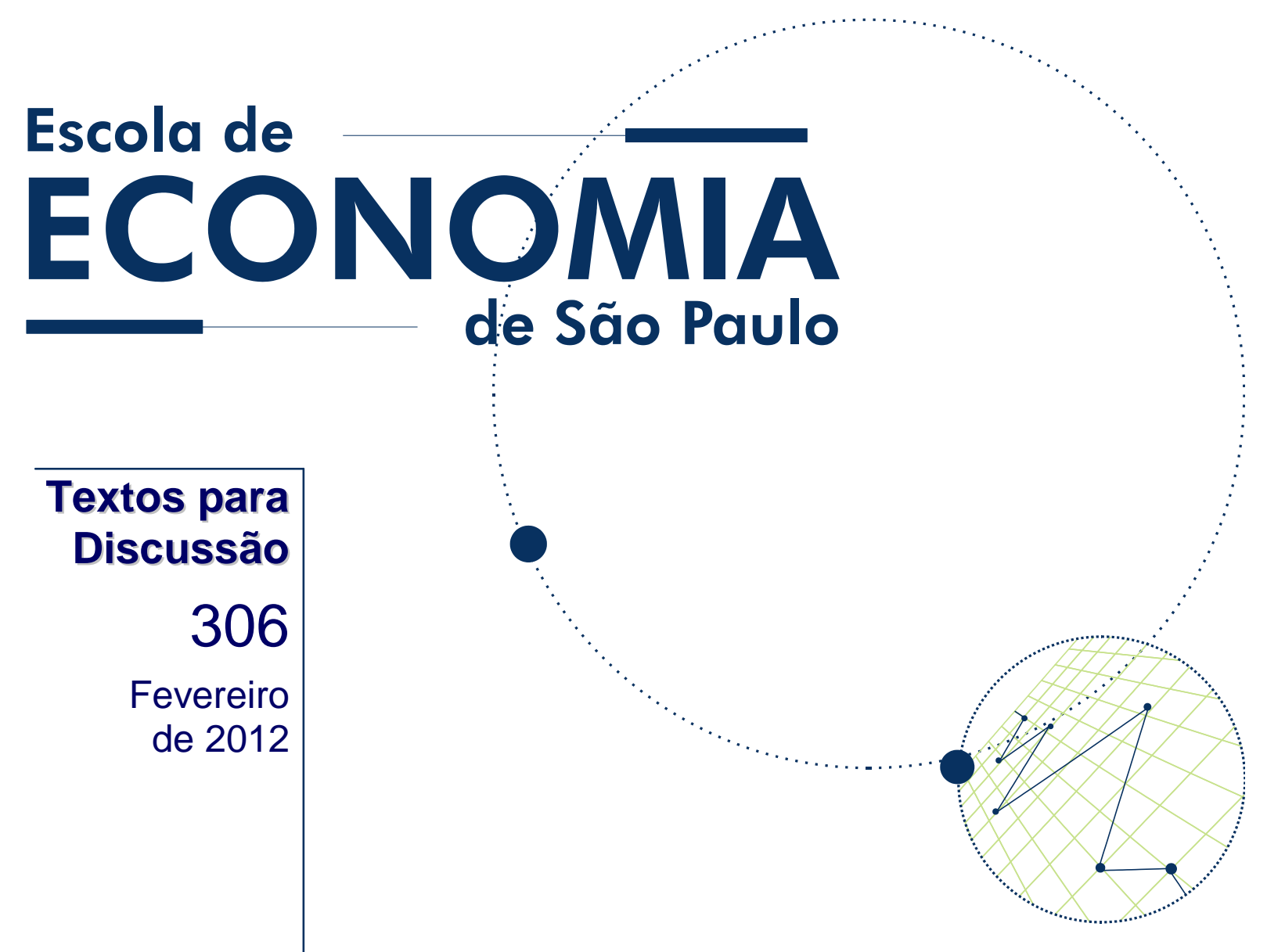

Why economics should be a modest and reasonable science

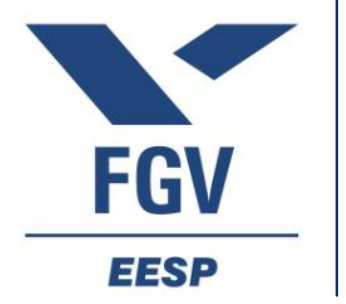

LUIZ CARlos BRESser-PEREIRA 


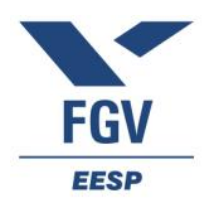

Os artigos dos Textos para Discussão da Escola de Economia de São Paulo da Fundação Getulio Vargas são de inteira responsabilidade dos autores e não refletem necessariamente a opinião da FGV-EESP. É permitida a reprodução total ou parcial dos artigos, desde que creditada a fonte.

\section{Escola de Economia de São Paulo da Fundação Getulio Vargas FGV-EESP} www.eesp.fgv.br 


\title{
Why economics should be a modest and reasonable science
}

\author{
Luiz Carlos Bresser-Pereira
}

Paper presented to the annual meeting of the Association for
Evolutionary Economics (AFEE), receiving the James Street
Scholar for 2012, and participating from the panel
"Institutionalism and the Great Crisis", Chicago, January 7, 2012.

\begin{abstract}
Unlike the methodological sciences such as mathematics and decision theory, which use the hypothetical-deductive method and may be fully expressed in complex mathematical models because their only truth criterion is logical consistency, the substantive sciences have as their truth criterion the correspondence to reality, adopt an empirical-deductive method, and are supposed to generalize from and often unreliable regularities and tendencies. Given this assumption, it is very difficult for economists to predict economic behavior, particularly major financial crises.
\end{abstract}

Key words: probability, uncertainty, modesty, method, neoclassical economics

JEL Classification: B-300 B-400

Economics or political economy is a major social science, because it has as its object something that is central to human life: the economic system, how people organize labor and production, and how they allocate income - in other words, because men and women dedicate a large part of their existence to work and make a living in market-coordinated economic systems that economics seeks to understand and explain. Yet economics should be a modest science, because, as with all other social sciences, its best models - the models that really make sense - are simple and open; or because its predictive power is limited in so far as (thank God) men and women continue to be free individuals making choices under uncertainty and according to criteria that are not constant. Consequently, economists or policymakers should also be modest and reasonable; they must acknowledge that they have a limited capacity to predict the future. The members of the Association for Evolutionary Economics know that well. They are structuralist and institutionalist economists who reject "pure" economics, and see economics as a social or historical science: a science where theory is 
supposed to predict the economic behavior of free individuals - of agents who are miles away from the atoms and the cells of the natural sciences. With heartfelt thanks to the AFEE for the James Street Scholar for 2012 that it has awarded me, I thought this was the right moment to say how I view our science.

Today we are still in the midst of the long crisis that began with the 2008 crash. In this historical circumstance, economists should be particularly modest, because the central cause of the crisis was the arrogance of the economic models that justified "scientifically" the deregulation of financial markets. What does it mean for a social science to be arrogant? Essentially, it means supposing that a social science can be as precise as the methodological sciences, particularly mathematics, or, at least, as precise as the natural sciences. It means developing closed models that supposedly encompass all the relevant variables, ignoring that this is impossible for the sciences that deal with human beings, who are endowed with freedom and, for that reason, are inherently unpredictable. If natural scientists who deal with highly predictable physical particles or with reasonably predictable life cells and genes are modest, because they know how complex the object of their research is, economists should be much more modest.

\section{The arrogance of neoclassical economics}

When we develop economic theories we must limit the level of abstraction of our claims. For sure, the more abstract and general the theory the better it is, because it will be simple and encompassing; but, as a trade-off, it may lose contact with economic reality - with a reality that is historical. As Geoffrey Hodgson (2001: 4) remarks, "the desire for a general theory obliges scientists to simplify and to overturn the very generality for which they strive. The lure of a general theory is in part responsible for a degree of neglect of history in contemporary economics and sociology". This is particularly true of mainstream economics. Neoclassical economics - essentially, the general equilibrium model, rational expectations' macroeconomics, neoclassical growth models, and the theory of efficient financial markets - is highly abstract and general, but the trade-off was not just between generality and an incapacity to deal with a complex and changing historical reality. This kind of cost can always be managed 
by eliminating simplifying assumptions. The real trade-off was between generality and science. The outcome was not scientific models, because neoclassical economists adopted an inappropriate scientific method. Instead of doing what natural and social scientists are supposed to do - namely, to look for regularities and tendencies in the substantive object of study (in the case of economics, economic systems) and to generalize from them - neoclassical economists sat in their armchairs and deduced the whole neoclassical model from homo economicus and the law of diminishing returns. This methodological choice - the decision to use in the development of a substantive science, as economics is, a method that is not suited to it but to the methodological sciences (sciences that have no object, but are an aid to thinking) - leads to the construction of an essentially mistaken body of knowledge - of an ideological system without predictive power but with poisonous consequences: allowing for the adoption of policies and non-policies that just increase inequality and exacerbate the financial instability of economic systems.

To the extent that the hypothetical-deductive method allowed for the building of a "precise" or "mathematical" science, its practitioners became arrogant, owners of a "pure" and fully rational science based on the mathematical concept of optimization or of Pareto optimality. The more they believe that human beings or economic agents are rational, the more arrogant their economics will be, because the stronger will be their claim to precision; because the more certain will they be of the truthfulness of their claims - a truthfulness whose criterion is not correspondence to reality (the correct criterion for the substantive sciences), but logical consistency (the correct criterion for the methodological or adjective sciences).

The classical definition of man - "man is the rational animal" - remains valid. Man is the only animal capable of being rational. On the other hand, the economic system that economics seeks to understand and interpret is capitalism, a social organization in which, for the first time in history, production obeys the rationality principle - with profit as the objective and with capital accumulation 
embodying technological progress as the most adequate means to achieve that objective. ${ }^{1}$

Thus, men are capable of being rational, but are they rational? What does it mean to be rational, and to what degree are men rational? The definition of what it means to be rational in economic terms is far from agreed. Some say that an agent is rational when he or she maximizes his or her economic interests; others, that an individual is rational when he or she chooses reasonably adequate means to achieve distinct goals among which are economic interests. The degree of the rationality of economic agents is also open to debate: whether they are fully rational, as neoclassical economics supposes, or whether, besides making compromises among economic and other objectives, they do not necessarily choose the most appropriate means to achieve them.

If men were fully rational, a hypothetical-deductive method would be appropriate, because the theories based on such an assumption would precisely predict economic actions. But if they are not so rational, as recent research by behaviorist psycho-economists has definitively demonstrated, this method becomes meaningless; worse than that, it becomes a source of erroneous assessments of how economic systems work.

Economics wants to be the "queen" of the social sciences if not a natural science, because it largely uses mathematics to express its models. Absurdly, for many of its practitioners models are scientific only when they are formalized, when they are expressed in mathematical terms. In so far as they use a hypotheticaldeductive method - that is, they use axioms to deduce the theory - the theory is mathematics-friendly. But it is not science-friendly, because the deductions that it derives from the assumption of full rationality are intrinsically and necessarily wrong. Friedman (1953) is wrong when he says that we may treat the behavioral axioms "as if" they were true because the predictions derived from this "scientific" method would be correct. On the contrary, predictions are most of

1 On this matter see the classical analysis of Celso Furtado in Chapter 3 of Furtado (1961). 
time wrong; they lead to major policy errors, and cause major harm. They may be true, but only by accident.

The challenge that economics faces is not to conserve the hypothetical-deductive method and to be nevertheless realistic. Also, it is not to conserve the method and to claim that economics is an "inexact science". This last approach is the one adopted by Daniel Hausman (1992: 2). He says that "the method of economics is deductive, and confidence in the implications of economics axioms depends on the confidence in its axioms rather than from testing their implications". In this passage I would just substitute "neoclassical economics" for "economics". But he adds: "in my view many of the basic principles of economics are inexact laws..." And, instead of facing the full consequences of his lack of confidence in the axioms of neoclassical economics, he retreats: "... and the methods of theory appraisal that economists employ are scientifically acceptable". This is inconsistent. If neoclassical economists depend more on axioms than on testing, and if they produce an inexact science, how can I say that their method is acceptable?

\section{Probability}

Keynes did not fall into this error because, although originally in the neoclassical tradition, he eventually adopted a historical-deductive or empirical-deductive method. ${ }^{2} \mathrm{He}$ did not share the Platonist belief that an intrinsic or immanent rationality exists that philosophers and scientists are supposed to discover. The only great economist who consistently adopted the hypothetic-deductive method was Alfred Marshall, but in reality he was founding a new methodological science - economic decision-making theory - in which the hypothetical-deductive method is legitimate. When he was doing economics, his analysis was always distinctly historical.

2 I originally contrasted the historical-deductive method and the hypothetical-deductive method in Bresser-Pereira (2009). 
Rather than a Platonist, Keynes was an Aristotelian in so far as he believed in the existence of an outward and contradictory reality, and his criterion for assessing reality was not pure reason but reasonableness. This approach is clearly apparent in his concept of uncertainty as defined in the General Theory of 1936. When, 16 years before, he wrote his A Treatise on Probability (1921), he was still thinking primarily in deductive terms; as Donald Gillies (2006: 200) remarks, "Keynes' basic idea was that probability constitutes a generalization of deductive logic". But he wanted also to convey that scientific propositions and arguments are always probabilistic: that you never can definitively reach the truth, but you can pragmatically define as true the best knowledge that you have so far been able to attain. For Keynes (1921: 4), it was impossible to define probabilities mathematically, but men are able to define it intuitively, using their judgment. He argued that in so far as we use our knowledge to define how probable a future event is, "probability may be called subjective. It is not, that is to say, subject to human caprice. When once the facts are given which determine our knowledge, what is probable or improbable in these circumstances has been fixed objectively, and in independence of our opinion." Thus, for Keynes, probability is a rational belief based on available knowledge; in this sense, it is an opinion, but "this opinion is, for the nature of the case, incapable of positive proof".

According Athol Fitzgibbons (1988: 14), Keynes's approach to probability was based on "strong evolutionary reasons". In other words, to assess probability Keynes counted with historically obtained knowledge, and submitted this knowledge to logical intuition: "the field of probability extends beyond common sense, and rational intuition has important implications for the scientific method which are not so generally accepted...The logical theory of probability therefore represented a challenge to the primacy of the scientific method and scientific knowledge". Gillies (2006: 201) reasons along the same lines: "How do we obtain knowledge about this logical relation of probability? Keynes' answer is that we get to know at least some probability relations by direct acquaintance or immediate logical intuition."

Keynes agreed with Hume that practical men should act on probabilistic knowledge, but he rejected the philosopher's skepticism. For Keynes, we don't 
know the true causes but we know the probabilities and act accordingly. We derive our assessment of probabilities from observation or induction - from the generalization of the observations made. Thus, Keynes pragmatically rejected Hume's famous "problem of induction", that is, the proposition that we cannot deduce general laws from induction because this would imply "ampliative inference" - a jump from a number of observations to the truth - which would not be justifiable. The classical example of this is the black swan. After observing thousands of white swans we are led to say that all swans are white, but there is always the possibility that a black swan may appear. This reasoning is logically true - ampliative inference is not fully justifiable in rational terms - but it is justifiable in reasonable terms. While I see many white swans and don't see a black one, I will believe that it is true that all swans are white, and I will orient my actions accordingly. But I should be aware that I might eventually see a black swan that will refute my belief. Keynes (1921: 241) does not derive high probability from simple or pure induction, but when induction is associated with "analogy" and reasoning. As Tiziano Raffaelli (2006: 169) notes, "in the footsteps of Bacon and Mill, Keynes maintains that induction is an active process of the mind, not a blind enumeration of cases". To quote Keynes directly (1921: 240):

In the case, however, of most scientific arguments, which would commonly be called inductive, the probability that we are right, when we make predictions on the basis of past experience, depends not so much on the number of experiences upon which we rely, as on the degree in which the circumstances of these experiences resemble the known circumstances in which the prediction is take to effect.

Following Keynes, what I am proposing is a pragmatic response to Hume's problem: to continue to make generalizations from our empirical or historical observations, following statistics and econometric rules, but to be humble enough in relation to our findings, always to recognize that they are provisional truths. This is what I call a "reasonable" response. There are two other possibilities: one is to become skeptical or relativist; this is pronounce the death of science. The other is to condemn induction and to substitute the consistency criterion for the empirical one, the logical criterion for the correspondence to reality criterion; this is also to reject science, in so far as we understand that the substantive sciences (natural as well as social) necessarily have correspondence to reality as their truth criterion. As Fausto Vicarelli (1983: 161-162) remarked, 
Keynes used the "inductive method" in the General Theory to develop his own theory and also to explain how entrepreneurs formed expectations and make their investment decisions. He complements the use of all the information available on markets, specifically "the intensity of effective demand, the existing quantity of capital goods and trends on the stock market", with reasoned or logic knowledge, and takes the decision. The decision is taken under uncertainty, because he does not really know the future, but "the strength of this conception thus lies in the way the argument is based on the most objective possible datum, namely observed reality. The subjective factor exists: it lies however in the choice of the aspects of reality taken as a starting point."

\section{Regularities}

According to a Platonist or rationalist approach this alternative would be legitimate, not because objective reality does not exist, but because this reality would be "rational". This was essentially Descartes' philosophical demarche. Physics and astronomy seemed consistent with this view - which I believe to be essentially wrong -, because the regularities that the researcher finds in the physical world are significant. That is why physicians complement so successfully empirical research with deductive reasoning. Instead, in the case of economics, economists must be more parsimonious in deductive reasoning. Economics is not an exact science like physics, because humans are not atoms, because the regularities that we are able to find in physics we don't find in economics by observing free men and women. While in physical reality there are regularities that derive from the constant patterns displayed by the atoms that constitute it, the regularities that we find in human behavior are limited and provisional. While we can predict the behavior of atoms with precision, we may assign only modest probabilities to the prediction of human behavior.

But the fact that regularities are significant in physics does not mean that neutrons and electrons act rationally. They just act regularly. In the living world, cells act less regularly, and in the social world men and women act still less regularly. As a previous winner of an AFEE award, Adolph Lowe (1980: 229), noted in his acceptance speech, neoclassical economics adopted two axioms that 
are at the root of science since the Greeks but that do not apply to the social sciences, namely, the "autonomy" and the "inherent orderliness" axioms. The first axiom "takes for granted the existence of an outside world, moving independently of man's volition"; the second, that there is "an inherent orderliness in the research object". If these two axioms are questionable in relation to physics, and still more debatable in relation to biology, they make no sense in relation to economics.

Paul Davidson (1982: 65) founded his post Keynesian critique of neoclassical economics on the rejection of this inherent orderliness of economic systems, or, in his terms, on the rejection of the "ergodic axiom". According to him, neoclassical economists mistake precision for accuracy, and "prefer to be precisely wrong to be roughly right and accurate". He explains:

The axiom of ergodicity permits economists to act "as if" they were dealing with a "hard" science where data are homogeneous with respect to time. In the ergodic world, observations of a time series realization (i.e., historical data) are useful information regarding the probability distribution of the stochastic process, which generated that realization.

In more recent work, Davidson distinguishes the ergodic from the ordering axiom that assumes that at any point in time people "know" all the possible future outcomes of any action taken today. The ergodic axiom says practically the same thing, just adding statistical reasoning. In relation to it, Davidson (2007: 32) adds:

The ergodic axiom therefore assumes that the outcome associated with any future data can be reliably predicted by statistical analysis of already existing data obtained either from time series or cross-sectional data. The future is therefore never uncertain.

Note that this is not a critique of econometric research, which is just a tool to allow us to have a little more confidence in our prediction of future events. Econometrics may assume an ergodic world, but its practitioners are supposed to know that research outcomes must be taken cum grano salis. This critique is directed toward "pure" or neoclassical theory, whose formal models are not based on econometric research, on the observation of reality, but on the axioms of ergodicity, of inherent orderliness, and of homo economicus. Econometric research is not deemed to add confidence to neoclassical models that would be 
true by definition, because they are demonstrable as are mathematical theorems, logically; econometrics exist to test hypotheses.

\section{Uncertainty and decision making}

Uncertainty is another concept that was central to Keynes's view of economics economics as a social, not a natural, science. As Robert Delorme (2010: 70) underlines, “Keynes' view on uncertainty in social and human science, and specially in economics, denotes a radical departure from the perspective of natural science and of 'classical' theory". It appears as a fundamental concept in the General Theory (1936a), but it is fully explained only in the paper that Keynes published in the same year in the Quarterly Journal of Economics (1936b). His concept of uncertainty holds that the future is essentially uncertain, and represents the recognition that we are unable to predict the future. We may assign subjective probabilities to certain future events - always-weak probabilities despite the rigor of our econometrics - but it makes no sense to assign probabilities to most future events. It is more reasonable to acknowledge that we just don't know. In his words:

By "uncertain" knowledge, let me explain, I do not mean merely to distinguish what is known for certain from what is only probable... The sense in which I am using the term is that in which the prospect of a European war is uncertain, or the price of copper and the rate of interest twenty years hence, or the obsolescence of new inventions, or the position of private wealth-owners in the social system in 1970 . About these matters there is no scientific basis on which to form any calculable probability whatever. We simply do not know. (1936b: 213)

According to Hyman Minsky (1975: 57), "to understand d Keynes it is necessary to understand his sophisticated view about uncertainty, and the importance of uncertainty in the economic process. Keynes without uncertainty is something like Hamlet without the Prince." To Minsky, while classical economics and the neoclassical synthesis were based on a "barter paradigm", Keynes included money in it and developed a "speculative-financial paradigm". While uncertainty was relatively minor in a barter economy, in a modern speculative economy it is central.

Since at least the 1950s, future business executives have learned in the MBAs of the major business schools that the manager is the person who takes decisions 
under uncertainty. Decisions are not necessary when we know for sure what the consequences of our actions are. In this case, we just take the optimum course; we turn into neoclassical "optimizers", and business executives would not be necessary. For Keynes, they are very necessary not only because it is difficult to assign probabilities to future events, but also because in many cases probabilities become so uncertain that is best just to acknowledge that we just don't know. As Davidson (2007: 32) remarks, "true uncertainty occurs whenever an individual cannot specify and/or order a complete set of prospects regarding the future". Or, to derive the consequence of such a definition, true uncertainty is the daily experience of businesspersons and more broadly of economic agents.

Nevertheless, businesspersons must decide. As Marx underlined, active capitalists or entrepreneurs accumulate capital in their search for profits. But, as Keynes pointed out, to do that they face uncertainty and, for that reason, they have no alternative but to have recourse to a mix of reasoning and intuition, of courage and ambition, which he called "animal spirits". Indeed, uncertainty is something that makes rational calculus as limited as it is necessary. It is for this reason that economics - the science that studies and tries to predict the behavior of economic systems - must be humble or modest.

It is also for this reason that many economists, frustrated with the imprecision of economics, developed a new and very necessary methodological science decision-making theory - and mistook it for economics: a social science. While economics has as its object economic systems or market-coordinated systems, and requires an empirical or historical-deductive method to be developed, decision-making theory is a methodological science like mathematics and econometrics, a science in which the hypothetical-deductive method is wholly acceptable because it has no object, but just the objective of helping us to think and to make choices in conditions of uncertainty. Marshall's microeconomics becomes an extraordinary scientific accomplishment when we see it not as the microfoundation of economics but as a major attempt to develop decision theory - particularly economic decision making or decision-making in the context of markets - a theory whose second major contribution is game theory. 


\section{The historical-deductive method}

In economics, a proposition is true not because we believe that it describes rational behavior, but because it is a generalization of observed and repetitive behavior. Besides having definitions and classifications of economic concepts, we are able establish causal relations, but we never can claim from one cause or new fact that the same consequence always and necessarily follows, as neoclassical economics does. Instead, we are allowed to say only that one fact "generally" follows another. When we use the hypothetical-deductive method, empirical studies serve only to confirm something that we already know to be right because it is "rational", because it maximizes the interest of the individual economic agent, while when we adopt the historical-deductive method, the empirical observations associated with loose hypotheses are the subject matter from which we infer generalizations. After we have been able to develop a full theory, it will retain its value so long as subsequent observations continue basically to confirm it. That is why econometric studies are so valuable. In contrast, when the choice is the hypothetical-deductive method, observations that don't validate the theory are just nuisances, are the consequence of market failures that, once eliminated, will show the immanent and necessary truth of the theory.

When we use inductive reasoning we must be modest, because we never know that what we are saying is true. We hope that it is true, we believe that it is probably true, because our empirical studies point in that direction, but we are uncertain, we know that our capacity to predict the future is limited, that the behavior of markets does not follow an ergodic path, that in market-coordinated societies there is no inner or immanent rationality but an extremely complex process whereby men and women express their interests and their values, their fears and their hopes, their survival instinct and their convivial or solidarity instinct. In other words, we know that social and economic reality is contradictory and requires dialectical reasoning. Our propositions about cause and effect are always half true or two-thirds true because correlated factors are also present that operate in the opposite direction. 
Nevertheless, despite the limitations of the historical method, it is important to have the courage to generalize and to build a theory. The classical economists, including Marx, knew that, and built a system of knowledge about the capitalist economies of their time. We cannot say the same of the German Historical School, which in the second part of the $19^{\text {th }}$ century made a major contribution to the understanding of the German economy and to the economic policies that oriented its late industrialization. Thorsten Veblen, also an institutionalist, was critical of his German counterparts, although the theorizing of the American Institutionalist School was hardly more developed. ${ }^{3}$ After that, Keynes and Kalecki displayed boldness in creating macroeconomics, and the structuralist economists in creating development macroeconomics. Today, a large group of economists, principally in Brazil, are developing a structuralist development macroeconomics. ${ }^{4}$

When I criticize neoclassical economics for being immodest, and the old institutionalists for being too modest, while praising classical and Keynesian economics, I do not subscribe to the pedestrian belief that "the truth in the middle". For me, neoclassical economics is essentially wrong because it uses the wrong method. Neoclassical economists are sometimes right in their analysis and in their policymaking, not because they adopt general equilibrium micro and rational expectations macro models, but, yes, because they use concepts and propositions that are part of "general economics" - of a basic economics that is present in good introductory texts - and because they are intelligent and experienced economists. The immodest mathematical models that they learned in their graduate courses are not a support of but an obstacle to their reasoning.

In conclusion, a science based on regularities and tendencies is always relatively loose because economic agents are not always rational, because they face basic uncertainty in decision-making, because conventions or institutions condition behavior, and because economic events are non-ergodic - which precludes

${ }^{3}$ On this critique, see Lowe (1980).

${ }^{4}$ See Bresser-Pereira $(2010,2011)$. 
regularity and prevision. The consequence is that economics must be a modest science, a reasonable science and a pragmatic science. A modest science because its models are not micro-founded mathematical castles in the air, but simple relations that must be permanently checked against reality - a reality whose structure and institutions are permanently changing; and because its generalizations are always provisional and as uncertain as economic behavior. A reasonable science because men and women are reasonable beings, not purely rational ones. And a pragmatic science, because growth and financial stability are major political objectives of modern democratic societies, and because economists are supposed to make sensible diagnoses of economic and financial problems and to offer reasonably effective policy recommendations to deal with them.

\section{References}

Backhouse, Roger E. \& Bradley W. Bateman (eds.) (2006) The Cambridge Companion to Keynes, Cambridge: Cambridge University Press.

Bresser-Pereira, Luiz Carlos (2009) "The two methods and the hard core of economics", Journal of Post Keynesian Economics 31 (3): 493-522.

Bresser-Pereira, Luiz Carlos (2010) Globalization and Competition, Cambridge: Cambridge University Press.

Bresser-Pereira, Luiz Carlos (2011) “Structuralist macroeconomics and new developmentalism", Discussion Paper EESP/ Getulio Vargas Foundation, TD298, August 2011.

Davidson, Paul (1982 [1992]) International Money and the Real World, New York: St. Martin's Press. $2^{\text {nd }}$. Edition.

Davidson, Paul (2007) John Maynard Keynes, Houndmills: Palgrave Macmillan.

Delorme, Robert (2010) Deep Complexity and the Social Sciences: Experience, Modelling and Operationality, London: Edward Elgar.

Fitzgibbons, Athol (1988) Keynes' Vision, Oxford: Clarendon Press.

Friedman, Milton (1953) "The methodology of positive economics", in Milton Friedman, Essays in Positive Economics. Chicago: University of Chicago Press. 
Furtado, Celso (1961 [1967]) Development and Underdevelopment, Berkeley: University of California Press.

Gillies, Donald (2006) “Keynes and probability”, in Roger E. Backhouse and Bradley W. Bateman (2006): 199-216.

Hausman, Daniel M. (1992) The Inexact and Separate Science of Economics, Cambridge: Cambridge University Press.

Hausman, Daniel M. (1999) "Ultra-deductivism, perfect knowledge and the methodology of economics", Journal of Economic Methodology 6 (1): 125-131.

Hodgson, Geoffrey M. (2001) How Economics Forgot History, London: Routledge. Keynes, John Maynard (1921) A Treatise on Probability, London: Macmillan.

Keynes, John Maynard (1936a) The General Theory of Employment, Interest and Money, London: Macmillan.

Keynes, John Maynard (1936b) “The general theory of employment”, Quarterly Journal of Economics, 51 (2): 209-223.

Lowe, Adolph (1980 [1987]) "What is evolutionary economics? Remarks upon receiving the Veblen - Common Award", in Adolphe Lowe, Essays in Political Economics, New York: New York University Press: 226-233. Originally published in the Journal of Economic Issues (1980).

Minsky, Hyman P. (1975) John Maynard Keynes, New York: Columbia University Press.

Rafaelli, Tiziano (2006) "Keynes and philosophers”, in Roger E. Backhouse and Bradley W. Bateman (2006): 160-179.

Vicarelli, Fausto (1983) "From equilibrium to probability: a reinterpretation of the method of the General Theory, in Fausto Vicarelli, ed. (1983 [1985]) Keynes's Relevance Today, London: Macmillan. Original Italian edition, 1983: 155-177. 